\title{
Community participation in Intangible Cultural Heritage safeguarding
}

\author{
Valentina L. Zingari
}

For citation: Zingari, Valentina Lapiccirella. 2020. Community participation in Intangible Cultural Heritage safeguarding. Pravovedenie 64 (1): 23-34. https://doi.org/10.21638/spbu25.2020.102

\begin{abstract}
According to the Convention for the Safeguarding of Intangible Cultural Heritage (ICH), social actors are at the core of the $\mathrm{ICH}$. Article 2 proposes a subjective, creative and dynamic definition of heritage based on community, groups and individuals (CGls), highlighting a spiritual connection: $\mathrm{ICH}$ safeguarding must respect the "sense of identity and continuity" of CGls - the main actors in the process of heritage transmission. This community-based vision of heritage is developed in the text of the Convention, the Operational Directives, and reinforced since 2016 by the Twelve Ethical principles introduced in the Basic Texts. A Convention is much more than a text: it determines political, social and cultural contexts, as well as processes of change. A normative tool conceived as guidelines for governments, permeates social life, becoming a framework for the actions and evolution of civil society. This article reflects on the following case study: the "Tocati Programme for the Safeguarding of Traditional Games and Sports" (TGS). The programme started in Verona, Italy in 2003, connecting a network of communities and building relationships through the organization of an international event: The "Tocati Festival of Games in the Streets". From the beginning, this social movement has strengthened the support of institutions at different levels, connecting people, communities and living traditions with representatives of institutions, researchers, artists and policymakers. The cultural association coordinating Tocati, Associazione Giochi Antichi (AGA) met the UNESCO ICH Convention in 2007. The author examines what has changed in the framework of the Convention in regard to the history of a community-based process and how the Tocati experience contributes to the effective implementation of the Convention today. An attempt is made to identify the key factors, actors and steps of the Tocati cultural, social and political process. This is a story that improves our understanding of the role of civil society in the complex, often conflictual and powerful dynamic of heritage-making.
\end{abstract}

Keywords: community, civil society, traditional games and sports, Intangible Cultural Heritage, safeguarding, community participation, UNESCO.

\section{Need of community and civil society creativity}

These journeys in the foreign lands of which a society is made up... indeed, culture can be compared to this art, conditioned by places, rules and data; it is a proliferation of inventions in confined spaces.

Michel de Certeau. Avant-propos à La culture au pluriel (1980) $)^{1}$

In the particular time we are living, during the Covid 19 pandemic, taking the time to question the "need of community" in our society is more pertinent than ever. In this

Valentina Lapiccirella Zingari - PhD Cultural Anthropologist, UNESCO Intangible Cultural Heritage Accredited Facilitator, 16, Strada di Palazzavelli, Siena, Sovicille, 53018, Italy; vzingari@gmail.com

1 De Certeau M. La culture au pluriel. Paris: Union Générale d'Éditions, 1974. P. 13.

2 See: Bauman Z. Community, seeking safety in an insecure world. Polity Press, Cambridge 2001. In the introduction, An Ouverture, Bauman affirm: "Words have meanings. Some words, however, also have a feel. The word 'community' is one of them" (Ibid. P. 1).

(c) St. Petersburg State University, 2021 
time of disruption, with museums, theatres and other "places of culture" closed, we are missing, and, therefore, looking for, a new imaginary of cultural heritage, focussed on the creativity of everyday life and civil society experiences. We need to be surprised by this creativity.

Around us in many sociopolitical exchanges, the word "community" is everywhere in several forms: loss of community, need of community, sense of community and individual responsibility in the community, are all common key-words. During the lockdown, confined in our individual spaces, we are also taking time for new reflections on the values of social life. Moreover, to respect the Covid 19 norms, following the recommendations of the scientific community for human health, generates common behaviors. In a time of emergency, norms show their necessity, limits and potential. This process has disclosed with surprising clarity how crucial it is to think and act in terms of cooperation and interconnection at the scale of the planet. Is the global framework of international Conventions getting more pertinent than ever in a context of global awareness-raising of ecological, economic, social and cultural challenges?

Several centuries ago, William Shakespeare told us: "There are more things in Heaven and Earth, Horatio, than are dreamt of in your philosophy" (Hamlet, Act 1, Scene 5). In the 1970s, Michel De Certeau, evoked "these journeys in the foreign lands of which a society is made up... indeed, culture can be compared to this art, conditioned by places, rules and data; it is a proliferation of inventions in confined spaces". Inviting us to turn toward an anthropology of everyday life, stating that "Everyday life is dotted with wonders": an extraordinary repertoire of unpredictable answers.

The civil society living projects and realisations has been, for me as a researcher in Human Sciences, a source of surprises and permanent challenges. Communities need our time and care. We need their experiences, struggles and wisdom: the living heritage of Humanity they embody and will to transmit to future generations.

In a recent letter, accompanying the UNESCO survey on Intangible Cultural Heritage $(\mathrm{ICH})$ during the pandemic we find the word disruption. The letter ends recalling that: "at the same time we are seeing how living heritage can be a source of resilience in such difficult circumstances, as people continue to draw inspiration, joy and solidarity from practising their living heritage"3.

In this complex and difficult global context, we are discovering how $\mathrm{ICH}-$ embodied in gestures, language and oral traditions, traditional games and food heritage, social practices and rituals - sustains people and communities in everyday life, as a source of resilience. This helps us to a new understanding of the meaning of $\mathrm{ICH}$ as Heritage that "communities, groups and individuals" constantly produce, connecting memory and creativity across the world.

\section{Time of communities: Intangible Cultural Heritage and community participation}

Everyday life is dotted with wonders.

Michel de Certeau. L'invention du quotidien (1994)

Starting this reflection on the relation between social life and norms, I wish to give visibility to some key concepts emerging from the text of the UNESCO Convention for the safeguarding of Intangible Cultural Heritage (2003 Convention) and the literature on community participation in the process of heritage-making. I will adopt the vision of Heritage

3 See: Living heritage experiences and the COVID-19 pandemic. Available at: https://ich.unesco. org/en/living-heritage-experiences-and-the-covid-19-pandemic-01123 (accessed: 20.09.2020). 
as a cultural process, in which historical and cultural narratives and meanings are created and recreated ${ }^{4}$ : a space of negotiation and compromise between different powers ${ }^{5}$, and a question of human rights.

The 2003 Convention is a normative tool, and legally-binding. Beyond the text, inspired by its words, its social meaning speaks the diverse and universal language of dreams, at work in human actions, transforming ideals in socio-political tools. What is the place/position of "communities, groups and individuals", the human beings, in this inspiring text? The question of community engagement in heritage identification and definition is central in the Convention and the 12 Ethical principles, today integrated in the Basic Texts of the Convention ${ }^{6}$. It is the core of the $\mathrm{ICH}$ definition, where "community sense of identity and continuity" is the key-factor legitimating the process of heritagemaking.

\section{Article 2 - Definitions}

For the purposes of this Convention

1. The "intangible cultural heritage" means the practices, representations, expressions, knowledge, skills - as well as the instruments, objects, artefacts and cultural spaces associated therewith - that communities, groups and, in some cases, individuals recognize as part of their cultural heritage. This intangible cultural heritage, transmitted from generation to generation, is constantly recreated by communities and groups in response to their environment, their interaction with nature and their history, and provides them with a sense of identity and continuity, thus promoting respect for cultural diversity and human creativity.

It is the main reference for any safeguarding activities, first of all the inventories of $\mathrm{ICH}$.

\section{Article 11 - Role of States Parties}

Each State Party shall:

a) take the necessary measures to ensure the safeguarding of the intangible cultural heritage present in its territory;

b) among the safeguarding measures referred to in Article 2, paragraph 3, identify and define the various elements of the intangible cultural heritage present in its territory, with the participation of communities, groups and relevant non- governmental organizations.

Article 15 of the 2003 Convention, is fully devoted to this crucial question.

Article 15 - Participation of communities, groups and individuals

Within the framework of its safeguarding activities of the intangible cultural heritage, each State Party shall endeavors to ensure the widest possible participation of communities, groups and, where appropriate, individuals that create, maintain and transmit such heritage, and to involve them actively in its management.

Taking into account the Operational Directives (O. D.) of the 2003 Convention $^{7}$, a living text evolving over time at the rhythm of the UNESCO ICH Convention statutory meet-

${ }^{4}$ See: Smith L. Heritage and its Intangibility // Skounti A., Tebbaa O. On the Intangibility of Cultural Heritage. Rabat, Marrakech: UNESCO Office, 2011. P. 11-21.

5 In reference to the presentation of Riecks Smeets, in the framework of the First Forum of ICH researchers, Paris 2012. Available at: https://www.culture.gouv.fr/Sites-thematiques/Patrimoine-ethnologique/Soutien-a-la-recherche/Colloques-seminaires-et-journees-d-etude/2012/9e-Journeedu-Patrimoine-Culturel-Immateriel-Premier-Forum-de-chercheurs-du-PCl-a-la-Maison-des-Culturesdu-Monde (accessed: 20.09.2020).

6 See: Text of the Convention for the Safeguarding of the Intangible Cultural Heritage. Available at: https://ich.unesco.org/en/convention (accessed: 20.09.2020).

7 See: Operational Directives for the implementation of the Convention for the Safeguarding of the Intangible Heritage. Available at: https://ich.unesco.org/en/directives (accessed: 20.09.2020). 
ings, we find the concept of community participation substantiated by concrete indications, aiming to translate into practice the $\mathrm{ICH}$ concepts. O. D. 79 and 80 recommend the establishment of cooperation and coordination mechanisms, assuring the widest and effective participation of communities, groups and individuals

79. Recalling Article 11 (b) of the Convention and in the spirit of Article 15 of the Convention, the Committee encourages States Parties to establish functional and complementary cooperation among communities, groups and, where applicable, individuals who create, maintain and transmit intangible cultural heritage, as well as experts, centres of expertise and research institutes.

80. States Parties are encouraged to create a consultative body or a coordination mechanism to facilitate the participation of communities, groups and, where applicable, individuals, as well as experts, centres of expertise and research institutes, in particular in:

a) the identification and definition of the different elements of intangible cultural heritage present on their territories;

b) the drawing up of inventories;

c) the elaboration and implementation of programmes, projects and activities;

d) the preparation of nomination files for inscription on the Lists, in conformity with the relevant paragraphs of Chapter 1 of the present Operational Directives;

e) the removal of an element of intangible cultural heritage from one List or its transfer to the other, as referred to in paragraphs $38-40$ of the present Operational Directives.

O. D. 81 and 82 recommend capacity building of communities and measures to raise the awareness on the values of $\mathrm{ICH}$.

81. In conformity with the provisions of Articles 11-15 of the Convention, States Parties shall undertake appropriate measures to ensure capacity-building of communities, groups and, where applicable, individuals.

82. States Parties shall take necessary measures to raise the awareness of communities, groups and, where applicable, individuals regarding the importance and value of their intangible cultural heritage, as well as of the Convention, so that the bearers of this heritage may fully benefit from this standard-setting instrument.

O. D. 86 encourages the development of networks composed by communities, experts, centres of expertise as well as joint and interdisciplinary approaches, in relation to "elements of ICH they have in common".

86. States Parties are encouraged to develop together, at the subregional and regional levels, networks of communities, experts, centres of expertise and research institutes to develop joint approaches, particularly concerning the elements of intangible cultural heritage they have in common, as well as interdisciplinary approaches.

Integrating this "community, groups and individual" level, the Non-Governmental Organisations (NGO) accreditation system is an important framework proposed by the Convention for an effective involvement of civil society in the fabric of heritage. It directly and openly connects NGO worldwide with the ICH Secretariat, without any filter by Stateparties, involved in a later stage in the accreditation procedure via the Evaluation Body recommendations and the Intergovernmental Committee decisions.

90. In conformity with Article 11 (b) of the Convention, States Parties shall involve the relevant non-governmental organizations in the implementation of the Convention, inter alia in identifying and defining intangible cultural heritage and in other appropriate safeguarding measures, in cooperation and coordination with other actors involved in the implementation of the Convention. 
The NGO mediation role is analysed in some scientific publications as crucial for the empowerment of the community to achieve effective participation in the ICH safeguarding process $^{8}$. Civil society organisations play an essential role, as often the same communities, composed by practitioners and bearers of $\mathrm{ICH}$, can organise themselves under associative forms. A multiplicity of different modalities is possible, also in the framework of the crucial mechanism of NGOs-ICH accreditation system. Operational Directive 108 affirms that Community centres and associations that are "created and managed by communities themselves" can play a vital role in supporting the transmission of $\mathrm{ICH}$.

Community centres and associations that are created and managed by communities themselves can play a vital role in supporting the transmission of intangible cultural heritage and informing the general public about its importance for those communities. In order to contribute to raising awareness about intangible cultural heritage and its importance, they are encouraged to:

a) be used by communities as cultural spaces in which their intangible cultural heritage is safeguarded through non-formal means;

b) be used as places for transmitting traditional knowledge and skills and thus contribute to intergenerational dialogue;

c) serve as information centres about a community's intangible cultural heritage.

In chapter VI of the Operational Directives, devoted to the safeguarding of ICH and Sustainable Development at the national level, a large set of key words are used as concrete tools for collaborative actions. O. D. 170 and 172 underlines the value of research made by "communities and groups themselves", recommending, at the same time, to facilitate cooperation with relevant experts, cultural brokers and mediators through a participatory approach, to sustain safeguarding efforts.

Let us take a rapid overview of the scientific literature related to $\mathrm{ICH}$ and the roles of heritage professionals and NGOs in the process of heritage-making.

The effective synthesis of Chiara Bortolotto in the book "Le patrimoine culturel immatériel. Enjeux d'une nouvelle catégorie"9, started with an overview on the "participation of communities" evocating the "desire for community", identified by Zygmunt Baumann as main expression of a widespread need of cultural belonging in the contemporary "liquid society". Reflecting on the origin and development of the ICH paradigm, this overview recognises a possible role of experts and researchers as "cultural broker". In this same book, Valdimar Hafstein reflects on the social and political uses of the $\mathrm{ICH}$ paradigm, focussing on the process where "references to $\mathrm{ICH}$ contribute to a cultural claim that structures the social field", affirming that "the Intangible cultural heritage is the community"10. Frédérique Maguet analyses the different conception of Democracy, between French universalism and the Anglo-Saxon "right to the differences", evocating the Axel Honneth analysis of political philosophy, defining democracy as a "community of communities"11.

Mediation, "pragmatic posture", engagement, sharing authority, advocacy, are the key-words of an unfolding vision of heritage, which aims to facilitate the understanding of the "logics of social actors" by listening to their narratives, translating languages and putting in dialogue different levels of social action: between civil society actors, policy-makers and representatives of Institutions. In the UNESCO documents, we find an interesting definition proposed by some experts in 2006 :

${ }^{8}$ See in particular: Jacobs M., Neyrink J., Van Der Zeijden A. UNESCO, Brokers and Critical Success (F)Actors in safeguarding Intangible Cultural Heritage. Gent: Volkskunde, 2014. P. 432.

${ }^{9}$ Le patrimoine culturel immatériel. Enjeux d'une nouvelle catégorie / ed. C. Bortolotto. Paris: Editions de la Maison des sciences de l'Homme, 2011. P. 251.

10 Hafstein V. Célébrer les differences, renforcer la conformité // Ibid. P. 86.

11 Maguet F. L'image des communautés dans l'espace public // Ibid. P. 55. 
Communities are networks of people whose sense of identity or connectedness emerges from a shared historical relationship that is rooted in the practice and transmission of, or engagement with, their $\mathrm{ICH}^{12}$.

This notion of network is even more pertinent in the contemporary evolutions of social and political life, particularly in the democratic experience of European countries, evolving in a globalized world. If the UNESCO 2003 Convention opens the way to change, to a new "time of communities" in the language/practices of cultural policies, the Council of Europe Framework Convention on the value of Heritage for Society, propose an interesting and complex definition of "heritage community".

Article 2-Definitions

For the purposes of this Convention,

a) cultural heritage is a group of resources inherited from the past which people identify, independently of ownership, as a reflection and expression of their constantly evolving values, beliefs, knowledge and traditions. It includes all aspects of the environment resulting from the interaction between people and places through time;

b) a heritage community consists of people who value specific aspects of cultural heritage which they wish, within the framework of public action, to sustain and transmit to future generations.

In a recent publication, Marc Jacobs observes that "the underlying idea is that of a network of different actors, both (groups of) living human beings and institutions"13.

\title{
3. "Tocati, a shared programme for the safeguarding of Traditional Games and Sports": A relevant case-study to question the social life/uses of normative tool
}

\author{
There are more things in Heaven and Earth, Hora- \\ tio, than are dreamt of in your philosophy.
}

William Shakespeare, Hamlet, Act 1, Scene 5

A concrete community-based project, "Tocatì,a shared programme for the safeguarding of Traditional Games and Sports", allows us to reflect on the norm as a tool for living process and social uses, observing how a community project involves policy-makers, institutions and other stakeholders at different levels. From the text to the field we can see, and in this case state, the pertinence of the Convention at work. The Tocatì casestudy helps us to reflect on the role of communities, groups and individuals together with NGOs, experts, mediators and Institutions in the co-creation process of heritage-making, between the willingness to safeguard $\mathrm{ICH}$ in the dynamic and creative sense of heritage as a common good, as proposed by the 2003 Convention, and the communities claims of a recognition as cultural actors in the public space. In order to "see the connections", we propose looking at the history of Tocatì: a civil society process of heritage-making, taking inspiration in the 2003 Convention as a framework for community-empowerment and a shared tool supporting a complex networking and safeguarding process.

In the following description we show, in a chronological order, some of the main moments of the Tocati evolution, keeping in mind the coherence between this experience and the Operational Directive key-concept and references, which we analysed in section

12 UNESCO-ACCU 2006. Available at: https://ich.unesco.org/doc/src/00034-EN.pdf (accessed: 20.09.2020).

${ }^{13}$ Jacobs $M$. CGls and Intangible Heritage Communities, Museum engaged // Museums and Intangible Cultural Heritage. Towards a Third Space in the Heritage Sector. Bruges: Werkplaats Immaterieel Erfgoed, 2020. P. 39. 
II. This evolution shows, at the same time, the factors and actors progressively involved in the ongoing safeguarding process.

In 2002 an informal group of practitioners "born to save a Traditional game (S-ciancoLippa)" 14 , claiming its right to use the public space to practice their traditional game, in the centre of the Italian historical town of Verona. The first public event, at the local level, has an unexpected success with an important public participating to this first "Torneo di S-cianco Città di Verona"15.

In 2003 a newly-born cultural association - Associazione Giochi Antichi (AGA) organised the first edition of "Tocatì (in local language, 'it is your turn', a popular expression used during the game), Festival dei Giochi in strada" a national event including a lot of different traditional games from the surrounding regions and the whole of Italy ${ }^{16}$. The festival decides to pay attention not only to the games in itself, but to the communities of players, practitioners and bearers as cultural actors, considering the traditional game as an element of local cultures. In this sense, Tocatì insists on cultural diversity as a value and on traditional games as expressions connected with other elements of community's living heritage. Traditional games with their diversity connect communities across geographical distance, building creative cultural bridges ${ }^{17}$.

In 2004, AGA organised the first "Tocatì, Festival internazionale dei Giochi in strada international festival of games in the streets". Inviting ludic communities from other context of Italy and Europe to join Verona, sharing diverse living traditions in an open, interconnected, creative and innovative vision of heritage as a sociocultural ecosystem based on a fabric of relationships: the first international network of Tocati is on the road ${ }^{18}$. The event has been an unexpected success, returning the city to its inhabitants while opening it to the world. AGA, with some relevant efforts, obtained the support of its municipality and of the Veneto Region for the Festival organisation ${ }^{19}$. Since the very beginning, with the "Host of Honour" format, AGA invites a country or region of the world to join Verona bringing together some main groups practicing traditional games, as well as other $\mathrm{ICH}$ practitioners of this same region: traditional dances, music, crafts and foods transform the Verona centre in a colourful landscape devoted to the host traditions, highlighting the values of traditional games and sports as elements of $\mathrm{ICH}$. In this way, Tocati avoids specialization and professionalisation, with a strong care for the "real" and "authentic" community-dimension of the invited groups. This same attention is devoted to avoiding any form of commercialisation of heritage, ensuring the free access of everybody to public spaces. The sponsors of the Festival cannot impose their brand around the spaces de-

14 This sentence is a citation of the AGA president, Giorgio Paolo Avigo, in several interviews, conserved in the AGA archives.

15 See the AGA web site and past editions of this local event. Available at: https://www.associazionegiochiantichi.it/s-cianco/trofeo-citta-di-verona (accessed: 20.09.2020).

16 See: Tocati Festival Internazionale dei Giochi in Strada. Available at: https://tocati.it/edizioni/ edizione-2003/ (accessed: 20.09.2020).

17 For general literature on traditional games and sports, see: Jeux traditionnels, sports et patrimoine culturel / ed. by P. Parlebas. Culture et Education. Paris: L'Harmattan 2016. In this same book, see the article: Joauen G. Jeux traditionels d'adultes et environnement institutionnel. P. 39-59. On the Tocatì network case study: Berti F., Zingari V. L. Between similarities and cultural diversities: Intangible Cultural Heritage meets intercultural education. The example of Traditional Sports and Games // Proceeding of the first International Conference of the Journal Scuola Democratica. 2009. Vol. III: Governance, Values, Work and Future. P.70-76. Available at: https://www.scuolademocratica-conference.net/wp-content/ uploads/2019/11/1st-SD-Conf.-Proceedings-Vol.-3.pdf (accessed: 20.09.2020).

18 See: Operational Directives 79-81.

19 See: Operational Directives 105.b and c "promoting policies for public recognition of bearers and practitioners of Intangible Cultural Heritage". See also: https://www.associazionegiochiantichi.it/s-cianco/trofeo-citta-di-verona (accessed: 20.09.2020) and the Tocati website, https://tocati.it/ (accessed: 20.09.2020). 
voted to ludic performance: streets and squares are totally free, as in the every-day life of Italian villages where the communities come from.

In 2006 AGA negotiated the possibility of opening, in a public park of the historical centre of Verona, which has been a UNESCO World Heritage site since the year 2000, the "community centre" of the Casa Colombare. From this moment on, AGA has developed different permanent safeguarding activities, involving a local network of stakeholders together with schools, universities, museums and policy-makers, while connecting it with the world, via the international activities of the Festival ${ }^{20}$. In the Casa Colombare, a growing diversity of safeguarding activities is permanently in project and in process.

In 2007, the meeting with the European Traditional Games and Sports Association (AEJEST/ETSGA) ${ }^{21}$ opened the vision/activity of AGA to a stronger international commitment, and to an "infinity of relationships". ETSGA is an international network and a platform of exchange, improving the possibilities to develop joint approaches to safeguarding TGS, while encouraging the meeting between critical and interdisciplinary reflections developed the regional level and crossing different level of actions ${ }^{22}$. In this same period, ETSGA is applying for accreditation as an ICH NGO at UNESCO ${ }^{23}$. The European organisation has been involved since the beginning in the UNESCO working groups, contributing to the process of recognition of Traditional Games and Sports since 1999, the year of the important declaration of Punta del Est ${ }^{24}$. In the framework of the ETSGA meetings, AGA realizes the contact-points between its vision and the values expressed by the UNESCO Convention on the safeguarding of Intangible Cultural Heritage. These international exchanges raise awareness of the importance and originality of the Tocati project, reinforcing the identity of its community-based vision on safeguarding TGS as part of living heritage.

In 2008 a first network of ten Italian groups of players met and wrote a "Manifesto" 25 , proposing the criteria defining a "traditional ludic community", distinguishing these socialcultural local actors from sportive federations and others actors of the dominant sportive and professionalized environment. It was the starting moment of a community-based identification and documentation activity across Italy. This approach precedes the most recent concerns of the Evaluation Body established by the Convention ${ }^{26}$, opening a rich

20 See: Operational Directives 108 and 172.

21 For AEJEST/ETSGA. Available at: https://jugaje.com/?lang=en (accessed: 20.09.2020).

22 See: Operational Directives 86.

${ }^{23}$ For the 2003 Convention NGO accreditation system. Available at: https://ich.unesco.org/en/accreditation-of-ngos-00192 (accessed: 20.09.2020).

${ }^{24}$ With the Declaration of Punta Del Este, $\mathrm{n}$ 1999, UNESCO recognize for the first time Traditional games and sports as part of cultural heritage of our societies. In 2009, a second Collective Consultation held in Tehran aims to establish a UNESCO Advisory Committee and to propose a definition, or rather a definitional framework: "Traditional sport and games are motor activities of leisure and recreation which can have a ritual character. They are part of the universal heritage diversity. They are practiced in an individual or collective manner, deriving from regional or local identity; they are based on rules accepted by a group that organizes competitive or non-competitive activities. Traditional sport and games dispose of a popular character in their practice and in their organization, yet if turned into sport tend to be uniform and institutionalized. The practice of traditional and games promotes global health". Available at: https:// unesdoc.unesco.org/ark:/48223/pf0000252837 (accessed: 20.09.2020). In the 2003 Convention frame, the document available at: https://ich.unesco.org/en/social-pracAces-rituals-and-00055 (accessed: 20.09.2020) states that "Traditional sports and games are part of our intangible heritage and a symbol of cultural diversity of our societies".

${ }^{25}$ See: https://www.associazionegiochiantichi.it/associazione/filosofia/manifesto (accessed: 20.09.2020).

${ }^{26}$ See in particular: the Report of the Evaluation Body on its work in 2018 and 2019. Available at: https://ich.unesco.org/en/13com (accessed: 20.09.2020), ITH/18/13.COM/1016 (accessed: 20.09.2020). Intangible Cultural Heritage and Sports. Considering the recent trend with an increasing number of nomina- 
season of participatory experiences of auto-documentation, community-based research and non-formal capacity-building experiences ${ }^{27}$. This nascent community-network is the object of an original publication, made by AGA in collaboration with its network, devoted to a trip across Italy and its ludic cultures: "Italian Traditional games. Trip across Italy in play" ${ }^{28}$. This community-based research was a powerful tool to open, in Italy, a season of study and research in the framework of Institutional inventories of Intangible cultural heritage $^{29}$.

The shared claim of TGS as cultural activities finds in the ICH Convention a powerful tool and in the statutory meetings of the Convention a pertinent framework for networkbuilding activities, empowering the community in its safeguarding efforts. AGA develops a strong dialogue with the European Traditional Games and Sport Association (ETSGA), accredited NGO by the Intergovernmental Committee for ICH in 2010. In 2014, taking into account the cultural approach to the safeguarding of TGS as a living and community-based element of ICH, ETSGA propose to the AGA President to represent the European NGO in the UNESCO frame. This decision opens a new age in the relationship between AGA and other accredited NGO, as, inter alia, some Italian NGOs participating on a regular basis in the Intergovernmental Committees of the ICH UNESCO Convention ${ }^{30}$. The ICH NGO Forum $^{31}$, in particular, works like an empowerment platform, bringing together communities, civil society organisations and different experts active in the $\mathrm{ICH}$ safeguarding perspective, in dialogue with the UNESCO ICH Secretariat and States parties.

In the context of the 2014 Intergovernmental Committee and ICH NGO Forum, a dialogue born between AGA, other NGOs and some ICH experts, on the pertinence of the ongoing project of Tocati as a good safeguarding practice ${ }^{32}$. In this same period, the under-use of the Register of Good safeguarding practices was evocated in international discussions, as a challenge to be faced by States parties of the Convention for the years to come. Since the first discussions devoted to Tocatì, several communities and experts decided to engage and support the Tocatì programme and Festival nomination process as a good practice for the safeguarding of $\mathrm{ICH}$. The nomination process reinforces the

tions related to sports, the Evaluation Body discussed the boundary between traditional sports and games and their professional forms. When describing sports in their files, States Parties often focus on explaining their rules and system of organisation instead of concentrating on their value as cultural practices and the community roles. Concerns were raised as to whether sports and games are in conformity with Article 2 of the Convention and with the Ethical Principles for Safeguarding Intangible Cultural Heritage (Principles 1 and 6). The Body concluded that sports and games can be expressions of intangible cultural heritage when they are community-based practices with a clear cultural meaning and are constantly recreated and transmitted across generations and when the file focuses on their practice within a local community in a non-professional environment. The professionalization of traditional sports could undermine their status as intangible cultural heritage.

27 See: Operational Directives 81, 82, 86.

28 Giochi Tradizionali. Viaggio attraverso I'Italia che gioca. Associazione Giochi Antichi. Available at: https://www.ediciclo.it/libri/dettaglio/giochi-tradizionali-ditalia/ (accessed: 20.09.2020).

29 See, in particular: the Lombardy regional inventory. Available at: www.intangiblesearch.eu (accessed: 20.09.2020). Since 2018 AGA was in charge of a participatory documentation process, together with 12 ludic communities actives at the regional level.

30 The SiMBDEA Italian Association is an UNESCO accredited NGO since 2010. Available at: https:// ich.unesco.org/en/accredited-ngos-00331 (accessed: 20.09.2020).

31 See the page of the UNESCO ICH website devoted to the ICH NGO Forum. Available at: https://ich. unesco.org/en/ngo-forums-00422 (accessed: 20.09.2020).

32 See art. 18 of the 2003 UNESCO Convention. Available at: https://ich.unesco.org/en/convention (accessed: 20.09.2020). 
network-building, highlighting the connections between $\mathrm{ICH}$ and the sustainable development perspectives ${ }^{33}$.

Since 2016 an international symposium "Tocatì, a shared heritage" has taken place in the framework of the Festival every year, bringing together communities, experts and Institutions from several countries in shared critical reflections, developing and reinforcing the awareness raising process, while strengthening at the same time the motivations to work in the perspective designed by the criteria of the Register ${ }^{34}$. This central and regular moment devoted to the Tocati international network, reinforce the communities and Institution's dialogues: the pillar for the effective implementation of the Convention safeguarding perspectives.

Since 2017 the Tocati network promotes, with the support of the Central Institute for Intangible Heritage (ICPI) of the Italian Ministry of Cultural Goods and Activities (MiBACT) and the Cultural Sector of the Veneto Region, a capacity-building process at the national level: the "days of Intangible" brings together communities of practices, NGOs, experts and facilitators as part of the UNESCO global network of capacity building, as well as Institutions at all levels. This national process is strengthening the Italian community network, together with Institutions at the local, regional and national level ${ }^{35}$.

In 2018 an experimental inventory process was launched in cooperation with Lombardy Region ${ }^{36}$.

In 2019, in the process of preparation of the nomination file, the European partnership coordinated by the UNESCO Office of the MiBACT, identifies Tocatì as a shared cooperation programme, living through a permanent network of communities promoting a wide range of initiatives at all levels: from the local to the international one, reflecting the criteria of article 18. The nomination file has been sent to UNESCO in March 2020, during the Covid19 lock-down, by five States parties of the Convention: Italy (leader partner), Belgium, Cyprus, Croatia and France.

In 2020, a resilient Tocatì Festival, supported by new technologies, connected the Italian communities in a widespread event, in which groups from 17 Italian countries played simultaneously and live, via streaming, in an extraordinary dialogue with the groups in presence in Verona. New technologies and social channels have allowed communities from all over the world to follow and experience the festival together.

This broad international "heritage community" of Tocati is an example of "traditional ludic communities" connecting with one another and with Institutions, in a growing process of awareness raising and empowerment. The Tocatì example reveals to what extent the UNESCO Convention can be a powerful tool to reinforce and improve a communitybased safeguarding strategy, strengthening the capacity of communities to connect with experts in order to demonstrate the coherence of their approach/story with the "spirit of the Convention" 37 , while reinforcing the institutional trust in this community-based process. At the same time, the Convention is a tool for awareness raising of the communities, who progressively discover the many dimensions of the heritage values of traditional

${ }^{33}$ Chapter VI of the Operational Directive is devoted to ICH and Sustainable Development. Available at: https://ich.unesco.org/en/directives (accessed: 20.09.2020).

34 See: Operational Directives 79-81.

35 See: Operational Directives 81-82, and https://tocati.it/?s=le+giornate+dell\%27immateriale (accessed: 20.09.2020).

36 See: 2003 Convention, art. 12-15 and Operational Directives 80 and 86.

37 The "spirit of the Convention" is a term widely used by both government representatives and representatives of communities, NGOs and experts during the meetings of the Intergovernmental Committees and General Assemblies of the 2003 Convention. See: Jacobs M. The spirit of the Convention. Interlocking principles and Ethics for safeguarding ICH // International Journal on Intangible Cultural Heritage. 2016. Vol. 11. P. $71-87$. 
games and other social practices, engaging in the transmission, at the local as well at the global level, of their ICH to the new generations.

\section{References}

Bauman, Zygmunt. 2001. Community, seeking safety in an insecure world. Cambridge, Polity Press. Berti, Francesca, Lapiccirella Zingari, Valentina. 2009. Between similarities and cultural diversities: Intangible Cultural Heritage meets intercultural education. The example of Traditional Sports and Games. Proceeding of the first International Conference of the Journal Scuola Democratica 3: 70-76. Available at: https://www.scuolademocratica-conference.net/wp-content/ uploads/2019/11/1st-SD-Conf.-Proceedings-Vol.-3.pdf (accessed: 20.09.2020).

Bortolotto, Chiara, ed. 2011. Le patrimoine culturel immatériel. Enjeux d'une nouvelle catégorie. Paris, Editions de la Maison des sciences de l'Homme.

De Certeau, Michel. 1974. La culture au pluriel. Paris, Union Générale d’Éditions.

Hafstein, Valdimar Tr. 2011. Célébrer les differences, renforcer la conformité. Le patrimoine culturel immatériel. Enjeux d'une nouvelle catégorie, ed. by Chiara Bortolotto, 75-97. Paris, Editions de la Maison des sciences de l'Homme.

Jacobs, Marc. 2016. The spirit of the Convention. Interlocking principles and Ethics for safeguarding ICH. International Journal on Intangible Cultural Heritage 11: 71-87.

Jacobs, Marc, Neyrink, Jorijn, Van Der Zeijden, Albert. 2014. UNESCO, Brokers and Critical Success (F)Actors in safeguarding Intangible Cultural Heritage. Gent, Volkskunde.

Jacobs, Marc. 2020. CGls and Intangible Heritage Communities, museums engaged. Museums and Intangible Cultural Heritage. Towards a Third Space in the Heritage Sector, 38-41. Brugge, Werkplaats Immaterieel Erfgoed.

Maguet, Frederic. 2011. L'image des communautés dans l'espace public. Le patrimoine culturel immatériel. Enjeux d'une nouvelle catégorie, ed. by Chiara Bortolotto, 47-73. Paris, Editions de la Maison des sciences de l'Homme.

Parlebas, Pierre (ed.). 2016. Traditional games, sports and cultural heritage. Jeux traditionnels, sports et patrimoine culturel. Culture et Education. Paris, L'Harmattan.

Smith, Laurajane. 2011. Heritage and its Intangibility. Ahmed Skounti, Ouidad Tebbaa. De I'immatérialité du patrimoine culturel. Rabat, Marrakech, UNESCO Office.

Received: September 28, 2020

Accepted: December 23, 2020

\section{Участие общин в охране нематериального культурного наследия}

\section{В. Л. Дзингари}

Для цитирования: Zingari, Valentina Lapiccirella. 2020. Community participation in Intangible Cultural Heritage safeguarding // Правоведение. 2020. Т. 64, № 1. С. 23-34.

https://doi.org/10.21638/spbu25.2020.102

В соответствии с Конвенцией об охране нематериального культурного наследия (Intangible Cultural Heritage, ICH) социальные субъекты являются отправной точкой для определения ICH. Статья 2 Конвенции предлагает субъективное, творческое и динамичное определение этого наследия, основанное на сообществе, группах и индивидах (community, groups and individuals, CGls) и подчеркивающее их духовную связь: охрана $\mathrm{ICH}$ должна уважать «чувство идентичности и преемственности» основных участников процесса передачи наследия. Это общинное видение наследия развито в тексте Конвенции, Оперативных директивах и с 2016 г. подкреплено Двенадцатью этическими принципами, введенными в основные тексты. Конвенция - это гораздо больше, чем текст: она определяет политические, социальные и культурные контексты, а также процессы изменений. Нормативный инструмент, задуманный как руководящие принципы для правительств, проникает в социальную жизнь, становясь основой для действий и эволюции гражданского общества. Автор статьи размышляет над тематическим исследованием 
«Программа Токати по охране традиционных игр и видов спорта» (Tocatì Programme for the Safeguarding of Traditional Games and Sports, TGS). Эта программа стартовала в Вероне (Италия) в 2003 г., объединив сеть сообществ и построив отношения через организацию международного мероприятия «Фестиваль уличных игр Токати». С самого начала это общественное движение усиливало свою институциональную поддержку на разных уровнях, связывая людей, общины и живые традиции с представителями институтов, исследователями, художниками и политиками. Культурная ассоциация, координирующая фестиваль Токати, а именно Associazione Giochi Antichi (AGA), испытала воздействие Конвенции ЮНЕСКО ICH в 2007 г. Автор поставил перед собой вопрос о том, что Конвенция изменила в истории общинного процесса и как опыт Токати способствует эффективному осуществлению Конвенции сегодня. В статье идентифицируются ключевые факторы, акторы и этапы культурного, социального и политического процесса Токати. По мнению автора, эта история улучшает понимание роли гражданского общества в сложной, часто конфликтной и мощной динамике создания нематериального культурного наследия.

Ключевые слова: сообщество, гражданское общество, традиционные игры и спорт, нематериальное культурное наследие, участие общин, охрана, ЮНЕСКО.

Статья поступила в редакцию: 28 сентября 2020 г. Рекомендована в печать: 23 декабря 2020 г.

Дзингари Валентина Лапичирелла - PhD культурологии, аккредитованный координатор ЮНЕСКО по нематериальному культурному наследию (ICH), Италия, 53018, Совичилле, Сиена, Страда-ди-Палаццавелли, 16; vzingari@gmail.com 